\title{
Anxiolytic Effects of the MCH1R Antagonist TPI 1361-17
}

\author{
Cheol Lee • Gregory S. Parks • Olivier Civelli
}

Received: 11 June 2010 / Accepted: 1 July 2010 / Published online: 16 July 2010

(C) The Author(s) 2010. This article is published with open access at Springerlink.com

\begin{abstract}
Melanin-concentrating hormone $(\mathrm{MCH})$ is a hypothalamic neuropeptide that acts on the $\mathrm{MCH} 1$ receptor. MCH1R is expressed widely throughout the brain, particularly in regions thought to be involved in the regulation of stress and emotional response. The role of $\mathrm{MCH}$ in anxiety has been controversial, however. Central administration of $\mathrm{MCH}$ has been reported to promote or reduce anxiety-like behaviors. The anxiolytic activity of several MCH1R antagonists has also been debated. To address this issue, we have tested whether TPI 1361-17, a highly specific and high affinity MCH1R antagonist, exerts anxiolytic effects in two commonly used models of anxiety, the elevated plus maze and the light-dark transition test. We show that this MCH1R antagonist exerts potent anxiolytic effects in both assays. Our study therefore supports previous studies
\end{abstract}

C. Lee and G. S. Parks contributed equally to this work. This study was discussed at the GPCR2010 symposium in Kyoto.

C. Lee $\cdot$ G. S. Parks $\cdot$ O. Civelli $(\square)$

Department of Pharmacology, University of California Irvine, 369 Med Surge II,

Irvine, CA 92697, USA

e-mail: ocivelli@uci.edu

G. S. Parks · O. Civelli

Department of Developmental and Cell Biology,

University of California Irvine,

Irvine, CA, USA

O. Civelli

Department of Pharmaceutical Sciences,

University of California Irvine,

Irvine, CA, USA

C. Lee

Department of Anesthesiology and Pain Medicine,

College of Medicine, Wonkwang University,

Iksan, Korea indicating that MCH1R antagonists may be useful in the treatment of anxiety.

Keywords Melanin-concentrating hormone - Anxiety · G protein-coupled receptor $\cdot$ Neuropeptide

\section{Introduction}

Melanin-concentrating hormone $(\mathrm{MCH})$ was originally isolated from salmon pituitaries as a hormone that induces paling of the skin in teleost fish (Kawaguchi et al. 1983). Subsequently, $\mathrm{MCH}$ was identified in the mammalian hypothalamus as a cyclic nonadecapeptide (Vaughan et al. 1989). In mammals, MCH is expressed predominantly in neurons of the lateral hypothalamus and the zona incerta which project broadly throughout the brain to regions involved in the regulation of feeding, energy homeostasis, and mood related behaviors (Bittencourt et al. 1992). $\mathrm{MCH}$ exerts its physiological and behavioral effects through two $\mathrm{G}$ protein-coupled receptors, MCH1R (Bachner et al. 1999; Chambers et al. 1999; Lembo et al. 1999; Saito et al. 1999; Shimomura et al. 1999) and MCH2R (Sailer et al. 2001), but only the MCH1 receptor is expressed in rodents (Tan et al. 2002). MCH1 receptors are widely distributed throughout the CNS with particularly dense expression in the cortex, hippocampus, amygdala, locus coeruleus, and nucleus accumbens shell (Saito et al. 2001).

The prominence of MCH1R in limbic brain regions has led to studies on the role of the MCH system in stress and anxiety. The present conclusions of these studies, however, are controversial. Central $\mathrm{MCH}$ injection has been reported to be either anxiogenic (Smith et al. 2006) or anxiolytic (Monzon and De Barioglio 1999; Monzon et al. 2001) in the elevated plus maze. Microinjection of $\mathrm{MCH}$ into the 
nucleus accumbens shell, an area of the brain where $\mathrm{MCH}$ has been reported to potentiate dopamine signaling (Chung et al. 2009), promotes depression-like behavior (Georgescu et al. 2005). MCH1R knockout mice exhibit reduced anxiety (Roy et al. 2006; Smith et al. 2006) and depression-like behaviors (Georgescu et al. 2005) in several behavioral paradigms. Finally, several groups have used MCH1R antagonists to search for a link between the $\mathrm{MCH}$ system and anxiety. In 2002, the MCH1R antagonist SNAP-7941 was shown to produce anxiolytic effects in a social interaction test and to reduce separation induced vocalization in guinea pig pups (Borowsky et al. 2002). Additional MCH1R antagonists, SNAP 94847, ATC0065, ATC0175, and GW3430, were found to also be anxiolytic in acute and chronic anxiety behavioral paradigms (Shimazaki et al. 2006). However, it has also been reported that MCH1R antagonists are ineffective in anxiety paradigms (Basso et al. 2006) and that several of the MCH1R antagonists reported to be anxiolytic bind to targets other than MCH1R that could contribute to the observed anxiolytic effects (Basso et al. 2006), raising questions about whether inhibiting the $\mathrm{MCH}$ system is sufficient to produce anxiolytic effects.

The present study examined the anxiolytic effects of a MCH1 receptor antagonist, TPI 1361-17. This antagonist exhibits high affinity (nM) and is specific for the MCH1 receptor (Nagasaki et al. 2009). In contrast to previously reported MCH1R antagonists, TPI13161-17 does not cross the blood-brain barrier and is thus administered intracerebroventricularly (i.c.v.) which ensures that its central effects are not affected by peripheral MCH-related responses such as potential alterations in insulin levels (Pissios et al. 2007). TPI1361-17 was therefore tested on mice in two widely used behavioral assays for anxiety: the elevated plus maze and the light-dark transition paradigms.

\section{Materials and Methods}

\section{Animals}

Male C57BL/6 mice (National Cancer Institute, Bethesda, MD, USA; age, 7-8 weeks; weight, 23-25 g) were used in all experiments. The animals were group-housed (four animals per cage) under controlled conditions with a 12-h light-dark cycle and with ad libitum access to food and water. All animal experiments were approved by the University of California Irvine Institutional Animal Care and Use Committee.

\section{Drugs}

TPI1361-17 was dissolved in phosphate-buffered saline (pH 7.4) with $0.2 \%$ bovine serum albumin. Prior to i.c.v. injection, mice were briefly anesthetized with isoflurane and TPI1361-17 or vehicle was injected into the lateral ventricle (i.c.v.) with $2 \mu \mathrm{L}$ total volume using a Hamilton syringe as described previously (Laursen and Belknap 1986; Xu et al. 2004). Mice were allowed to recover for 20 min prior to anxiety testing. Following completion of the experiment, mice were euthanized and brains examined to confirm correct injection site. Animals with an injection site not in the lateral ventricle were excluded from the study. Approximately $95 \%$ of injections were correctly placed.

Chlordiazepoxide (Sigma-Aldrich, St. Louis, MO, USA) was dissolved on the morning of the experiment in saline. Five milligrams per kilogram of chlordiazepoxide or saline was injected i.p. in a volume of $4 \mathrm{ml} / \mathrm{kg} 20 \mathrm{~min}$ prior to behavioral testing.

\section{Elevated Plus Maze Paradigm}

The elevated plus maze task was performed as described previously with minor modifications (Koster et al. 1999; Xu et al. 2004). Briefly, the plus maze consisted of two open $(30 \times 5 \mathrm{~cm})$ and two wall-enclosed arms $(30 \times 5 \times 15 \mathrm{~cm})$ connected by a central platform $(5 \times 5 \mathrm{~cm})$ in a dimly lit room. The apparatus was elevated $75 \mathrm{~cm}$ above the floor. Mice were transferred in their home cages to the behavioral testing room $1 \mathrm{~h}$ prior to the start of behavioral testing. The test was started by placing a mouse in the central area of the plus maze facing a closed arm which the animal usually enters first. Exploratory behavior was monitored using an automated video motility system (Video Mot II, TSE, Bad Homburg, Germany). The numbers of entries into open arms, time in open and closed arms, total number of zone transitions, and latency until the first open-arm entry were recorded and quantified. Entries were defined as the body center of an animal entering a new zone.

\section{Light-Dark Transition Paradigm}

The light-dark transition test was performed as described previously (Koster et al. 1999; Xu et al. 2004). The lightdark box was divided into a lit compartment $(30 \times 20 \times$ $25 \mathrm{~cm})$ and a dark compartment $(15 \times 20 \times 25 \mathrm{~cm})$ connected by a $4-\mathrm{cm}$ tunnel in a dimly lit room. Mice were initially placed in the dark compartment. The number of entries into the light compartment, time in light compartment, and latency to enter light compartment during the 5-min test were recorded using the same program as was used for elevated plus maze experiments. Entries were defined as the body center of an animal entering a different compartment.

\section{Statistics}

All statistical analysis was performed using Graphpad Prism 5.0. Nonparametric variables such as the number of 
entries into each arm were analyzed by Pearson's chi-square test. All other parameters were analyzed by Student's $t$ test or one-way analysis of variance with Bonferroni post-test. In all experiments, ${ }^{*} p<0.05,{ }^{* *} p<0.01,{ }^{* * *} p<0.001$, and ${ }_{p} p<0.05$ vs $0.5 \mathrm{nmol}$ TPI-1361-17 group.

\section{Results}

\section{Light-Dark Transition Test}

The light-dark transition test was validated with mice injected with $5 \mathrm{mg} / \mathrm{kg}$ chlordiazepoxide or saline. Mice administered chlordiazepoxide spent significantly more time in the light compartment ( 74.12 vs $41.78, p<0.05$, Table 1), exhibited more entries into the light compartment (9.43 vs, $6.17 p<0.05$, Table 1 ), and had a shorter latency to first entry into the light compartment (11.23 vs 48.76, $p<$ 0.05 , Table 1) than vehicle injected control mice, indicating an anxiolytic effect.

A separate group of mice was injected i.c.v. with either 0.5 or $1 \mathrm{nmol}$ of TPI 1361-17 or vehicle and tested in the light-dark transition test. Mice injected with $1 \mathrm{nmol}$ TPI 1361-17 spent significantly more time in the light compartment (66.12 vs 32.02, $F_{2,27}=9.73, p<0.01$, Fig. $1 \mathrm{a}$ ), entered the light compartment more times ( 8.3 vs $5.6, F_{2,27}=3.55$, $p<0.05$, Fig. 1b) and had a shorter latency to first entry into the light compartment (16.46 vs $39.25, F_{2,27}=3.66, p<0.05$, Fig. 1c) than vehicle-injected animals, and also spent significantly more time in the light compartment than mice injected with $0.5 \mathrm{nmol}$ TPI $1361-17$ (66.12 vs $45.19, F_{2,27}=$ 9.74, $p<0.05$, Fig. 1a). Mice injected with $0.5 \mathrm{nmol}$ TPI 1361-17 exhibited trends toward reduced anxiety like behaviors (Fig. 1).

\section{Elevated Plus Maze}

To validate the assay, mice were injected with $5 \mathrm{mg} / \mathrm{kg}$ i.p. chlordiazepoxide or saline and tested on the elevated plus maze. Mice administered chlordiazepoxide showed a significant increase in time spent on the open arms (42.78 vs $20.44, p<0.05$, Table 1 ), and the number of entries into open arms (9.00 vs $4.78, p<0.05$, Table 1$)$, and exhibited a strong trend towards a shorter latency to first entry onto an open arm (Table 1).

A separate group of mice was injected i.c.v. with $1 \mathrm{nmol}$ TPI 1361-17 or vehicle and tested on the elevated plus maze. Mice injected with TPI 1361-17 spent more time on the open arms of the plus maze (38.9 vs $6.99, p<0.01$, Fig. 2a), and entered the open arms more frequently ( 7.6 vs 5.0, $p<0.05$, Fig. $2 \mathrm{~b}$ ) than vehicle-injected animals. TPI 1361-17 injected mice trended toward a shorter latency to first open arm entry (Fig. 2c).

\section{Discussion}

The elevated plus maze and light-dark transition tests are commonly used mouse models of anxiety-like behavior. Compounds with anxiolytic effects cause mice to spend more time in and enter more frequently the open arms of the elevated plus maze or the lit compartment of the light-dark box (Lister 1987; Bourin and Hascoet 2003). In the present study, we first used the benzodiazepine chlordiazepoxide to validate two assays, the light-dark transition test and the elevated plus maze paradigms, and then demonstrated that the selective MCH1R antagonist TPI 1361-17 exerts potent anxiolytic effects in these models.

There was no observed effect on the total number of transitions between zones in the elevated plus maze $(15.40 \pm$ 2.056 vs $17.90 \pm 1.224)$, indicating that central administration of TPI 1361-17 is not sedative, which is consistent with a previous report that TPI 1361-17 does not alter locomotor activity (Nagasaki et al. 2009). The fact that TPI 1361-17injected mice spend more time in the non-protected zones of both assays indicates that TPI 1361-17 exerts anxiolytic effects. A dose-dependent relationship is present for anxiolytic effects in the light-dark transition assay. Although it is not possible to accurately compare the magnitude of the anxiolytic effects of chlordiazepoxide and TPI 1361-17 as presented in this study due to

Table 1 Validation of light-dark transition test and elevated plus maze

\begin{tabular}{|c|c|c|c|c|}
\hline & \multicolumn{2}{|c|}{ Light-dark transition test } & \multicolumn{2}{|c|}{ Elevated plus maze } \\
\hline & Vehicle & Chlordiazepoxide & Vehicle & Chlordiazepoxide \\
\hline Time spent in open arms (s) & $41.78 \pm 7.29$ & $74.12 \pm 10.13^{*}$ & $20.44 \pm 3.44$ & $42.78 \pm 7.67^{*}$ \\
\hline Entries into light compartment/open arms & $6.167 \pm 0.87$ & $9.43 \pm 0.72 *$ & $4.78 \pm 0.57$ & $9.00 \pm 0.65 * * *$ \\
\hline Latency to first entry into light compartment/open arms & $48.76 \pm 14.90$ & $11.23 \pm 2.94 *$ & $37.38 \pm 7.27$ & $20.21 \pm 5.25$ \\
\hline
\end{tabular}

The effects of $5 \mathrm{mg} / \mathrm{kg}$ i.p. chlordiazepoxide on time spent in the light compartment/open arms, number of entries into the light compartment/open arms, and the latency to first entry into the light compartment/open arms in the light-dark transition test and elevated plus maze 
a

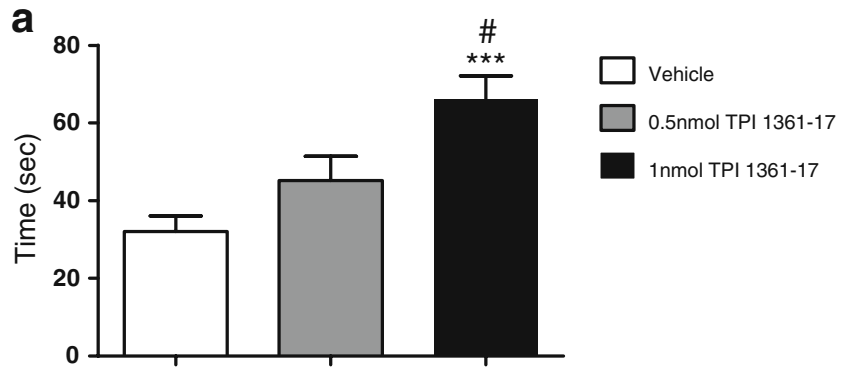

b

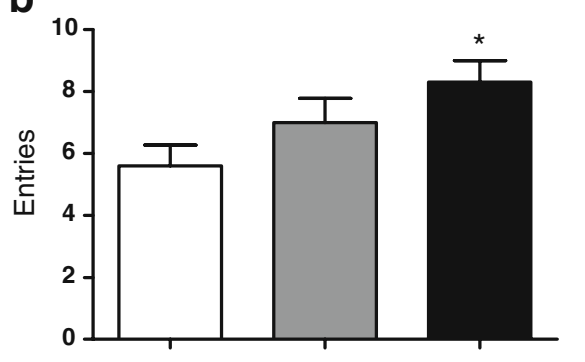

C

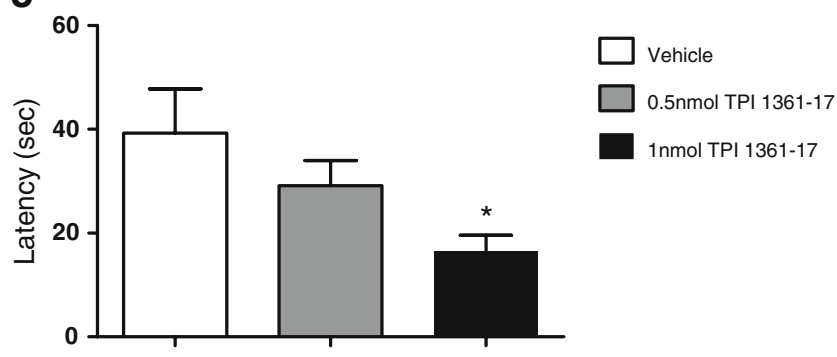

Figure 1 Light-dark transition test. The effects of i.c.v. injection of vehicle, $0.5 \mathrm{nmol}$ TPI $1361-17,1 \mathrm{nmol}$ TPI $1361-17$ on a time spent in the light compartment, b number of entries into the light compartment, and $\mathbf{c}$ and latency to first entry into light compartment $(N=9-10$ animals per group)

differences in experimental procedure, i.c.v. injection of TPI 1361-17 causes a reduction of anxiety-like behavior that appears similar to that observed with $5 \mathrm{mg} / \mathrm{kg}$ chlordiazepoxide i.p. in both behavioral paradigms, indicating that the inhibition of the MCH system has a potent effect on anxiety-like behavior.

TPI 1361-17 is a highly specific MCH1R antagonist that inhibits its receptor at nanomolar concentrations and does not display activity or binding to any targets tested in an array of G-protein protein coupled receptors and channels (Nagasaki et al. 2009). TPI 1361-17 has been shown to be effective in vivo, since it blocks MCH-induced food intake (Nagasaki et al. 2009) and inhibits acute cocaine selfadministration (Chung et al. 2009). The high degree of specificity indicates that the anxiolytic effects of TPI136117 are entirely due to blockade of the MCH system and that off-target effects are unlikely to contribute to the observed effect. Central administration of TPI 1361-17 eliminates the possibility of any peripheral effects of the compound contributing to the anxiolytic effects. This evidence supports $\mathrm{MCH}$ involvement in the regulation of anxiety and stress response (Smith et al. 2006, 2009) and is consistent with previous reports indicating that MCH1R antagonists are anxiolytic and may be useful in treating anxiety disorders.

The mechanisms underlying the anxiolytic activity of $\mathrm{MCH}$ antagonists are unknown, but several lines of evidence indicate that multiple factors may contribute to this effect. $\mathrm{MCH}$ has been reported to modulate the hypothalamic-pituitary adrenal axis (Smith et al. 2006, 2009), possibly by activating neurons in the paraventricular nucleus and increasing ACTH and corticosterone release (Herman et al. 1996; Smith et al. 2006), suggesting that $\mathrm{MCH}$ may regulate anxiety and stress response at least partially through this circuit. It has also been reported that microinjection of $\mathrm{MCH}$ into the nucleus accumbens shell induces depressive-like effects (Georgescu et al. 2005), and it was recently discovered that $\mathrm{MCH}$ modulates dopamine signaling in this region (Chung et al. 2009), suggesting that the effects of $\mathrm{MCH}$ on depression-like behavior may involve the dopamine system. Anxiety and depressive
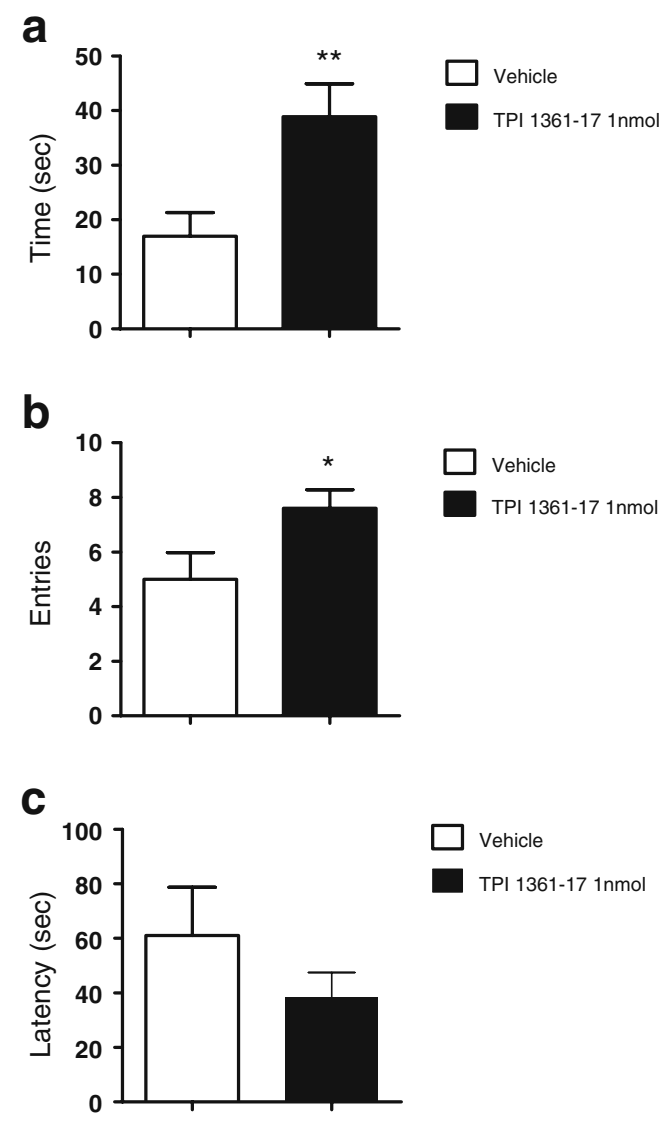

Figure 2 Elevated plus maze. The effect of i.c.v. injection of vehicle or 1 nmol TPI 1361-17 on a time spent on the open arm, b number of entries onto the open arm, and c Latency to first entry onto an open $\operatorname{arm}(N=10$ animals per group) 
disorders are closely linked and express with high comorbidity (Dunlop and Davis 2008), suggesting that the anxiolytic and antidepressant effects of $\mathrm{MCH}$ antagonists could occur through similar mechanisms and that the role of $\mathrm{MCH}$ in anxiety could thus also involve the mesolimbic dopamine system. Although little is known about the role of $\mathrm{MCH}$ in the amygdala, $\mathrm{MCH}$ projects to (Bittencourt et al. 1992) and MCH1R is highly expressed in several nuclei of the amygdala (Saito et al. 2001), in areas in which other neuropeptide systems are known to regulate anxiety (Tasan et al. 2010).

We have shown that acute central administration of the specific MCH1R antagonist TPI 1361-17 exerts potent anxiolytic effects in two of the most common and accepted anxiety behavioral paradigms. The high specificity of TPI 1361-17 indicates that its anxiolytic effects are caused by blockade of MCH1R alone. These results support previous studies indicating that MCH1R is a viable target for the development of novel anxiolytic drugs and suggests that the reported anxiolytic effects of other MCH1R antagonists are caused by blockade of the MCH system and are not due to off target effects.

Acknowledgement We thank Dr. Shinjae Chung for help during the study, Dr. James Belluzzi for advice on statistical analysis, and Dr. Rainer Reinscheid for equipment used in the study. This work was supported by grants MH60231, DA024746, and DK063001, the Eric L. and Lila D. Nelson Chair in Neuropharmacology and an Established Investigator Award from the National Alliance for Research on Schizophrenia and Depression (NARSAD) to O.C.

Open Access This article is distributed under the terms of the Creative Commons Attribution Noncommercial License which permits any noncommercial use, distribution, and reproduction in any medium, provided the original author(s) and source are credited.

\section{References}

Bachner D, Kreienkamp H, Weise C, Buck F, Richter D (1999) Identification of melanin concentrating hormone $(\mathrm{MCH})$ as the natural ligand for the orphan somatostatin-like receptor 1 (SLC-1). FEBS Lett 457:522-524

Basso AM, Bratcher NA, Gallagher KB, Cowart MD, Zhao C, Sun M, Esbenshade TA, Brune ME, Fox GB, Schmidt M, Collins CA, Souers AJ, Iyengar R, Vasudevan A, Kym PR, Hancock AA, Rueter LE (2006) Lack of efficacy of melanin-concentrating hormone-1 receptor antagonists in models of depression and anxiety. Eur J Pharmacol 540:115-120

Bittencourt JC, Presse F, Arias C, Peto C, Vaughan J, Nahon JL, Vale W, Sawchenko PE (1992) The melanin-concentrating hormone system of the rat brain: an immuno- and hybridization histochemical characterization. J Comp Neurol 319:218-245

Borowsky B, Durkin MM, Ogozalek K, Marzabadi MR, DeLeon J, Lagu B, Heurich R, Lichtblau H, Shaposhnik Z, Daniewska I, Blackburn TP, Branchek TA, Gerald C, Vaysse PJ, Forray C (2002) Antidepressant, anxiolytic and anorectic effects of a melanin-concentrating hormone-1 receptor antagonist. Nat Med $8: 825-830$
Bourin M, Hascoet M (2003) The mouse light/dark box test. Eur J Pharmacol 463:55-65

Chambers J, Ames RS, Bergsma D, Muir A, Fitzgerald LR, Hervieu G, Dytko GM, Foley JJ, Martin J, Liu WS, Park J, Ellis C, Ganguly S, Konchar S, Cluderay J, Leslie R, Wilson S, Sarau HM (1999) Melanin-concentrating hormone is the cognate ligand for the orphan G-protein-coupled receptor SLC-1. Nature 400:261-265

Chung S, Hopf FW, Nagasaki H, Li CY, Belluzzi JD, Bonci A, Civelli O (2009) The melanin-concentrating hormone system modulates cocaine reward. Proc Natl Acad Sci USA 106:6772-6777

Dunlop BW, Davis PG (2008) Combination treatment with benzodiazepines and SSRIs for comorbid anxiety and depression: a review. Prim Care Companion J Clin Psychiatry 10:222-228

Georgescu D, Sears RM, Hommel JD, Barrot M, Bolanos CA, Marsh DJ, Bednarek MA, Bibb JA, Maratos-Flier E, Nestler EJ, DiLeone RJ (2005) The hypothalamic neuropeptide melaninconcentrating hormone acts in the nucleus accumbens to modulate feeding behavior and forced-swim performance. J Neurosci 25:2933-2940

Herman JP, Prewitt CM, Cullinan WE (1996) Neuronal circuit regulation of the hypothalamo-pituitary-adrenocortical stress axis. Crit Rev Neurobiol 10:371-394

Kawaguchi H, Kawazoe I, Tsubokawa M, Kishida M, Baker BI (1983) Characterization of melanin-concentrating hormone in chum salmon pituitaries. Nature 305:321-323

Koster A, Montkowski A, Schulz S, Stube EM, Knaudt K, Jenck F, Moreau JL, Nothacker HP, Civelli O, Reinscheid RK (1999) Targeted disruption of the orphanin FQ/nociceptin gene increases stress susceptibility and impairs stress adaptation in mice. Proc Natl Acad Sci USA 96:10444-10449

Laursen SE, Belknap JK (1986) Intracerebroventricular injections in mice. Some methodological refinements. J Pharmacol Meth 16:355-357

Lembo PM, Grazzini E, Cao J, Hubatsch DA, Pelletier M, Hoffert C, St-Onge S, Pou C, Labrecque J, Groblewski T, O'Donnell D, Payza K, Ahmad S, Walker P (1999) The receptor for the orexigenic peptide melanin-concentrating hormone is a G-protein-coupled receptor. Nat Cell Biol 1:267-271

Lister RG (1987) The use of a plus-maze to measure anxiety in the mouse. Psychopharmacology (Berl) 92:180-185

Monzon ME, De Barioglio SR (1999) Response to novelty after i.c.v. injection of melanin-concentrating hormone $(\mathrm{MCH})$ in rats. Physiol Behav 67:813-817

Monzon ME, Varas MM, De Barioglio SR (2001) Anxiogenesis induced by nitric oxide synthase inhibition and anxiolytic effect of melanin-concentrating hormone $(\mathrm{MCH})$ in rat brain. Peptides 22:1043-1047

Nagasaki H, Chung S, Dooley CT, Wang Z, Li C, Saito Y, Clark SD, Houghten RA, Civelli O (2009) The pharmacological properties of a novel MCH1 receptor antagonist isolated from combinatorial libraries. Eur J Pharmacol 602:194-202

Pissios P, Ozcan U, Kokkotou E, Okada T, Liew CW, Liu S, Peters JN, Dahlgren G, Karamchandani J, Kudva YC, Kurpad AJ, Kennedy RT, Maratos-Flier E, Kulkarni RN (2007) Melanin concentrating hormone is a novel regulator of islet function and growth. Diabetes 56:311-319

Roy M, David NK, Danao JV, Baribault H, Tian H, Giorgetti M (2006) Genetic inactivation of melanin-concentrating hormone receptor subtype 1 (MCHR1) in mice exerts anxiolytic-like behavioral effects. Neuropsychopharmacology 31:112-120

Sailer AW, Sano H, Zeng Z, McDonald TP, Pan J, Pong SS, Feighner SD, Tan CP, Fukami T, Iwaasa H, Hreniuk DL, Morin NR, Sadowski SJ, Ito M, Bansal A, Ky B, Figueroa DJ, Jiang Q, Austin CP, MacNeil DJ, Ishihara A, Ihara M, Kanatani A, Van der Ploeg LH, Howard 
AD, Liu Q (2001) Identification and characterization of a second melanin-concentrating hormone receptor, $\mathrm{MCH}-2 \mathrm{R}$. Proc Natl Acad Sci USA 98:7564-7569

Saito Y, Nothacker HP, Wang Z, Lin SH, Leslie F, Civelli O (1999) Molecular characterization of the melanin-concentrating-hormone receptor. Nature 400:265-269

Saito Y, Cheng M, Leslie FM, Civelli O (2001) Expression of the melanin-concentrating hormone $(\mathrm{MCH})$ receptor mRNA in the rat brain. J Comp Neurol 435:26-40

Shimazaki T, Yoshimizu T, Chaki S (2006) Melanin-concentrating hormone $\mathrm{MCH} 1$ receptor antagonists: a potential new approach to the treatment of depression and anxiety disorders. CNS Drugs 20:801-811

Shimomura Y, Mori M, Sugo T, Ishibashi Y, Abe M, Kurokawa T, Onda H, Nishimura O, Sumino Y, Fujino M (1999) Isolation and identification of melanin-concentrating hormone as the endogenous ligand of the SLC-1 receptor. Biochem Biophys Res Commun 261:622-626

Smith DG, Davis RJ, Rorick-Kehn L, Morin M, Witkin JM, McKinzie DL, Nomikos GG, Gehlert DR (2006) Melanin-concentrating hormone-1 receptor modulates neuroendocrine, behavioral, and corticolimbic neurochemical stress responses in mice. Neuropsychopharmacology 31:1135-1145
Smith DG, Hegde LG, Wolinsky TD, Miller S, Papp M, Ping X, Edwards T, Gerald CP, Craig DA (2009) The effects of stressful stimuli and hypothalamic-pituitary-adrenal axis activation are reversed by the melanin-concentrating hormone 1 receptor antagonist SNAP 94847 in rodents. Behav Brain Res 197:284-291

Tan CP, Sano H, Iwaasa H, Pan J, Sailer AW, Hreniuk DL, Feighner SD, Palyha OC, Pong SS, Figueroa DJ, Austin CP, Jiang MM, $\mathrm{Yu} \mathrm{H}$, Ito J, Ito $\mathrm{M}$, Ito $\mathrm{M}$, Guan XM, MacNeil DJ, Kanatani A, Van der Ploeg LH, Howard AD (2002) Melanin-concentrating hormone receptor subtypes 1 and 2: species-specific gene expression. Genomics 79:785-792

Tasan RO, Nguyen NK, Weger S, Sartori SB, Singewald N, Heilbronn R, Herzog H, Sperk G (2010) The central and basolateral amygdala are critical sites of neuropeptide $\mathrm{Y} / \mathrm{Y} 2$ receptormediated regulation of anxiety and depression. J Neurosci 30:6282-6290

Vaughan JM, Fischer WH, Hoeger C, Rivier J, Vale W (1989) Characterization of melanin-concentrating hormone from rat hypothalamus. Endocrinology 125:1660-1665

$\mathrm{Xu}$ YL, Reinscheid RK, Huitron-Resendiz S, Clark SD, Wang Z, Lin SH, Brucher FA, Zeng J, Ly NK, Henriksen SJ, de Lecea L, Civelli O (2004) Neuropeptide S: a neuropeptide promoting arousal and anxiolytic-like effects. Neuron 43:487-497 